\title{
Nothing ventured, nothing gained! How and under which conditions employers provide employability- enhancing practices to their older workers
}

\section{Maria Fleischmann, Ferry Koster \& Joop Schippers}

To cite this article: Maria Fleischmann, Ferry Koster \& Joop Schippers (2015) Nothing ventured, nothing gained! How and under which conditions employers provide employability-enhancing practices to their older workers, The International Journal of Human Resource Management, 26:22, 2908-2925, DOI: 10.1080/09585192.2015.1004100

To link to this article: http://dx.doi.org/10.1080/09585192.2015.1004100

Published online: 17 Feb 2015.

Submit your article to this journal ¿

Џلll Article views: 405

View related articles $\sqsubset$

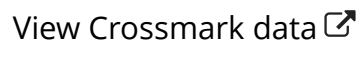




\title{
Nothing ventured, nothing gained! How and under which conditions employers provide employability-enhancing practices to their older workers
}

\author{
Maria Fleischmann $^{\mathrm{a}} *$ Ferry Koster $^{\mathrm{a}}$ and Joop Schippers ${ }^{\mathrm{b}}$ \\ ${ }^{a}$ Department of Sociology, Faculty of Social Sciences, Erasmus University Rotterdam, Rotterdam, \\ The Netherlands; ${ }^{b}$ Department of Economics, Faculty of Law, Economics, and Governance, Utrecht \\ University, Utrecht, The Netherlands
}

\begin{abstract}
Employability-enhancing practices usually refer to training or courses, but also practices directed towards older workers to sustain their work capability can be embraced by this term. In the context of an ageing population and workforce, older workers' labour market participation gains an increasingly important role. Therefore, the importance of employability-enhancing practices is noted as a solution to sustain their employment. In this study, we focus on employer-provided employability practices for older workers. We answer the following research question: which practices do employers use to enhance their older workers' employability and under which conditions are these practices adopted. Analyses on Dutch corporate data $(N=860)$ show that employers mainly provide employability-enhancing practices that are easily implemented and not expensive. This finding replicates prior research and clarifies that job redesign should be considered as a possibility to keep older workers in the labour market. Furthermore, our study shows that both organizational and labour market characteristics affect employers' decisions whether to provide employability-enhancing practices for their older workers. This suggests that policy measures might be necessary to assimilate investments in employability-enhancing practices across organizations.
\end{abstract}

Keywords: employability; employers; older workers; organization; personnel policy

\section{Employability-enhancing practices for older workers}

'Employability' is a well-known buzzword in the literature on human resource (HR) management. The term is used for different purposes: it can refer to individuals' work adaptability (Fugate, Kinicki, \& Ashforth, 2004), but often it denotes the policies or practices that enhance workers' skills and knowledge by investing in training (De Grip, Van Loo, \& Sanders, 2004; Hall, 2002). Because employability may refer to both workers' employability and the employability-enhancing policies or practices, it is necessary to be explicit about the meaning attached to the term. In the context of an ageing population, several actors regard employability investments as a possible measure to enhance older workers' labour market participation (De Grip et al., 2004; De Vries, Gründemann, \& Van Vuuren, 2001; Groot \& Maassen van den Brink, 2000). However, much emphasis has until now been put on individuals and the employability they possess, rather than considering how organizations can actively stimulate or generate workers' employability through the supply of employabilityenhancing practices (De Grip, Van Loo, \& Sanders, 1999; Fugate et al., 2004; Gazier, 1999, 2001). This article, therefore, specifically focuses on employers' role for employability investments by answering the research question which practices do employers use to enhance their older workers' employability and under which conditions are these practices adopted.

*Corresponding author. Email: fleischmann@fsw.eur.nl 
Posing this question is important for several reasons. First, knowledge about which employability-enhancing practices are valuable for older workers is limited. A reason for this is that there seems to be little agreement among researchers as well as policy makers regarding which practices stimulate older workers' employability. Often, it is assumed that by participating in formal training and courses, workers remain deployable within and across organizations (De Vries et al., 2001; Groot \& Maassen van den Brink, 2000; Picchio $\&$ van Ours, 2011). However, research shows that older workers report a low participation in these 'general' forms of employability-enhancing practices (Antikainen, 2001; Bishop, 1996; Canduela et al., 2012; Van Dalen, Henkens, Henderikse, \& Schippers, 2006). It is argued that increasing workers' employability through training or the participation in courses might be aimed towards younger workers, whereas older workers have different needs in order to sustain their employability and work capacity (Hedge, Borman, \& Lammlein, 2006; Tamkin \& Hillage, 1999). Prior research, therefore, often considers 'ageaware' or 'age-conscious' HR practices as employability-enhancing investments specifically directed towards older workers (Remery, Henkens, Schippers, \& Ekamper, 2003; Schaeps \& Klaassen, 1999). It is clear that stimulating and ensuring workers' employability has positive impacts for older workers' labour market participation. Higher work capability is found to increase the active participation of older workers in the labour force or to delay their retirement (Siegrist \& Wahrendorf, 2010; Siegrist, Wahrendorf, Von dem Knesebeck, Jürges, \& Börsch-Supan, 2007). Also switching to less demanding jobs or reducing working hours appears to enhance labour participation (Hurd \& McGarry, 1993). An enunciate difficulty is, however, that job redesign to enable and ensure these working conditions is hardly ever put into practice by employers and organizations (Conen, Henkens, \& Schippers, 2011; Hedge et al., 2006; Taylor \& Walker, 1998). Hence, by answering the research question, we provide new insights and guidance for researchers and practitioners alike with respect to practices that enhance older workers' employability.

Second, one of the reasons for the hesitant implementation of employability practices is that it is largely unclear who is responsible for this investment. On the one hand, individuals themselves can decide to engage in training or skilling to increase their employability (De Vries et al., 2001; Groot \& Maassen van den Brink, 2000). On the other hand, however, those individuals who are active on the labour market receive the largest part of employability-enhancing investments through their employers in order to perform better on the job (Forrier \& Sels, 2003). These investments are aimed at supporting workers' 'job match' or 'firm internal' employability rather than their 'external employability' (Sanders \& De Grip, 2004). This means, employer-provided employability-enhancing practices pay back for the firm, rather than that they make switching organizations more likely. Especially when employability enhancement for older workers takes the form of age-aware HR practices rather than (formal) training, employers have a crucial role as the 'decision makers' (Gazier, 2001). We, therefore, shift the focus to employers and organizations, as employers decide to which extent employabilityenhancing investments are made and who benefits from them (De Grip et al., 1999). By doing so, we generate knowledge about employers' role in the provision of employability-enhancing practices that can be used to formulate policy advice.

Third, in the literature, there is an elaborate discussion about factors relating to employer-provided employability. Several theoretical arguments hold that the returns from employability-enhancing practices are expected to be lower for older workers compared with their younger colleagues. This decreases the benefits for employers to provide these practices and make these investments. In line with this argument, prior research shows that employers are reluctant to invest in their older personnel's 
employability (Canduela et al., 2012; Chui, Chan, Snape, \& Redman, 2001; De Vries et al., 2001; Henkens, 2005; Karpinska, Henkens, \& Schippers, 2011; Taylor \& Walker, 1998; Van Dalen, Henkens, \& Schippers, 2010). Despite this general reluctance, there are several explanations under which employability-enhancing investments take place. We discuss not only rational decisions of employers (Becker, 1964; De Vries et al., 2001; Knoke \& Kalleberg, 1994), but also possible symbolic reasons to provide employabilityenhancing practices (Schein, 1985; Zacher \& Gielnik, 2014). Arranged according to arguments against and in favour of the provision of employability practices, we formulate expectations on the relation between investments in employability-enhancing practices and the share of older workers in an organization, the organization's size, the existent capital in the organization and how older workers are perceived within an organization. Furthermore, we argue that the labour market dependency of organizations might influence the investment in older workers' employability. By using theoretical arguments from different literatures, we provide an encompassing picture of employers' investment decisions, the role of organizational characteristics and the labour market. As knowledge on these is scarce, new insights will advance the discussion on employer-provided employability practices.

To investigate the above-stated research questions, we make use of an encompassing data set that we collected in spring 2012 among a random sample of Dutch employers from organizations with more than 10 employees. In the questionnaire, we asked for organizations' employability-enhancing practices regarding older workers. It also included questions about scarcity on the labour market and possible HR measures when facing an ageing workforce. Our analyses rely on 860 Dutch organizations and can thus provide an extensive picture of employability investment in the Netherlands.

\section{Employers' considerations regarding the provision of employability practices}

To theorize about employers' decisions whether to provide employability-enhancing practices and invest in their older personnel, we assume that employers are (bounded) rational, in the sense that they pursue 'goal-oriented' behaviour. This means that employers, rather than being fully rational and act upon complete information, take actions that they believe to increase the benefits of the organization (Kalleberg, Knoke, Marsden, \& Spaeth, 1996). We consider two conditions affecting employers' investment decisions, namely (1) characteristics of the organization and (2) characteristics of the labour market.

\section{Underinvestment in employability-enhancing practices}

Older workers are often regarded as being 'overpaid', meaning that they are paid more than their actual productivity (see e.g. Finkelstein \& Burke, 1998; Van Dalen et al., 2010; Warwick Report, 2006). From the view of neoclassical economics, it is assumed that earnings and productivity of a worker are directly related to each other. As this is however hardly ever observed in reality, Thurow (1975) introduced what became known as the 'seniority principle'. This term summarizes the finding that in the first career phase, the productivity of workers is often higher than their earnings, whereas in the second phase, earnings exceed productivity. Thus, although workers are generally underpaid in the first stage, they are overpaid in the second stage of their career. This long-term relation between productivity and earnings enhances workers' loyalty to the firm and makes it beneficial for employers to invest in their workers during the first part of the career. However, as wages increase with seniority, the costs older workers entail for employers 
become disproportionally high if retirement is delayed (Lazear, 1979). Thus, according to this theoretical framework, seniority wages reflect a burden for employers and, additionally, investments in older workers are unprofitable for two reasons. First, the costs associated with older workers would additionally increase if investments in workers' employability were made in the second phase of their career. Second, older workers will leave the organization rather soon for retirement. This means, the period investments pay off for older workers might be expected to be shorter compared with younger workers (Hedge et al., 2006; Warwick Report, 2006).

Another argument explaining why employers might hesitate to provide employabilityenhancing practices for their older personnel are stereotypes (for an encompassing review of the literature on age stereotypes, see e.g. Posthuma \& Campion, 2009). Literature on stereotyping states that due to missing information, employers cannot evaluate the productivity of each single worker. Thus, employers use their prior knowledge and general characteristics of workers, such as gender, age or type of work, as an estimate for productivity (Arrow, 1973; Phelps, 1972). Prior studies on employers' views indicate that they generally regard older workers as being less productive or flexible, and having a lower acceptance of new technologies (Chui et al., 2001; Henkens, 2005; Loretto, Duncan, \& White, 2000; Remery et al., 2003). This involves that employers assign a low willingness to gather training to older workers, and, thus, also provide fewer investments.

The seniority wages of older workers, the short pay-off period and also the stereotypes held by employers increase the costs that employers associate with older workers. These individual-level arguments can be translated into organizational-level hypotheses. Employers, who are active in organizations with a larger share of older workers, will experience higher costs when providing employability-enhancing practices. Thus, employers might decide to refrain from investing in their workers' employability. We therefore expect that the higher the share of older employees, the lower is the provision of employability-enhancing practices (H1: age hypothesis).

\section{Investment in employability-enhancing practices}

Next to the reasons underlining why investments are not taking place, there is much literature providing arguments in favour of the provision of employability-enhancing practices through employers.

From the 'marginal costs' argument, we know that the costs of investments do not increase linearly with, for example, the number of workers for whom the investment is made (Becker, 1964; Brown, Hamilton, \& Medoff, 1990; Knoke \& Kalleberg, 1994). The relative costs of providing employability-enhancing practices for an additional worker would, thus, be lower for organizations where this investment is made for a greater share of workers. Stated differently, the costs for employability practices decrease at the margin, because the investment for one additional worker is cheaper if the measure is already implemented for a 100 employees compared with if it is only implemented for 10. Hence, the costs of the investment in workers' employability marginally decrease with the size of the organization. Also other arguments would propose that investment (in formal training) is more likely in large organizations; for example, think of the more extensive internal labour markets of large organizations or the different setting in which large organizations are active (Knoke \& Ishio, 1994; Knoke \& Kalleberg, 1994). We, therefore, frame the following hypothesis: the larger the organization (in terms of the number of employees), the higher is the provision of employability-enhancing practices $(\mathrm{H} 2$ : organizational size hypothesis). 
From the marginal costs argument, a second hypothesis is deductible. As the marginal costs for investments decrease if the investment is made more often (Becker, 1964; Brown et al., 1990; Knoke \& Kalleberg, 1994), this allows a specification in our study: not only do costs of providing employability-enhancing practices decrease in larger organization, but especially if a greater share of employees is in need of these. Because especially older workers have a need to receive employability-enhancing practices, the costs of providing these practices are relatively seen lower in one organization compared with a same-sized organization employing a lower share of older workers. We, therefore, hypothesize that organizational size moderates the association between the share of older workers and the provision of employability-enhancing practices, such that the association is more positive for larger organizations (H3: age-size interaction hypothesis).

Human capital theory assumes that workers with a higher educational level or a longer tenure in the firm learn faster and with higher returns (Becker, 1964; Heckman, 2000; Mincer, 1962). This argument, often subsumed under the headline that 'learning begets learning' or 'skills beget skills', can also be translated into a rationale how organizational characteristics might affect the provision of employability-enhancing practices. For organizations that have the 'capital' of an on average higher educated workforce or one with a longer tenure, the provision of employability practices will be less costly and result in greater pay-offs. The human capital hypothesis, therefore, states that the higher the existent human capital is in an organization, the higher is the provision of employabilityenhancing practices (H4: existent human capital hypothesis).

Last, organizations might differently evaluate the idea whether older workers should be retained or whether older workers can provide benefits for the organization. On the one hand, there is much research showing that older workers are stereotyped (often by employers) as being less able, less productive or less motivated than their younger colleagues (Chui et al., 2001; Henkens, 2005; Loretto et al., 2000; McCann \& Giles, 2002; Remery et al., 2003). On the other hand, prior studies indicate that older workers' job performance increases with age (Cuddy \& Fiske, 2002; McCann \& Giles, 2002; Waldman \& Avolio, 1986). Hence, the question that arises is not only whether older workers are stereotyped positively or negatively, but rather whether there is a shared attitude or perception of older workers within an organization. This idea is explicated by the organizational culture theory of Schein (1990), which argues that organizations might share a specific view or perception, manifested in a 'culture'. In the case that workers internalize their leaders' (e.g. employers') views, this leads to the establishment of an organizational culture (Schein, 1985; Zacher \& Gielnik, 2014). In organizations where the perception of older workers is more positive, this might provide the basis for the implementation of employability-enhancing practices. We expect that the more positive the perception of older workers is, the higher is the provision of employability-enhancing practices (H5: perception hypothesis).

Besides organizational characteristics that are related to employers' decisions whether or not to provide employability-enhancing practices, the labour market in which organizations operate in will play a role. One such characteristic of the labour market is competition between organizations for the 'best' workers. In case of scarcity in labour supply, employers will experience more difficulty in filling vacancies, which might increase the competition between organizations. When organizations are facing scarcity, employers could increase the labour force participation of the existing workforce, take internal measures that enhance the organization's productivity or restrict the number of workers who leave their organization (De Grip et al., 2004; De Vries et al., 2001). Following insights from the literature on strategic management, organizations might want 
to use HR policies in order to attract or bind workers, to show that they 'care', and at the same time enhance their advantage over other organizations (De Vries et al., 2001; Knoke \& Kalleberg, 1994; Lado \& Wilson, 1994). Thus, employers might provide employabilityenhancing practices for their older workers in order to sustain work capability and keep their workforce attached to the organization. Our competition hypothesis reads that the higher the competition is on the labour market, the higher is the provision of employability-enhancing practices (H6: labour market competition hypothesis).

\section{Data, operationalization and methods}

\section{Data}

\section{Data collection}

To investigate the above-stated research question, we make use of an encompassing data set on Dutch employers that was collected as part of a larger project about social security in the Netherlands. For the questionnaire entitled 'Towards a greying workforce? HR policies for older workers', a random sample was drawn from the Dutch Trade Register ('Kamer van Koophandel'). Due to the generally very low response rate in corporate studies (Henkens, Remery, \& Schippers, 2008; Kalleberg et al., 1996; Van Dalen et al., 2006), we sampled 8000 organizations. Only organizations that are subscribed to have more than 10 employees were selected and the sample was stratified according to the size of the organization. To secure that enough large firms would participate in the questionnaire, they were oversampled (we applied base weights to correct for the oversampling, see below). The data collection took place between April and June 2012. After sending the questionnaires and cover letters by post mail, two reminders in postcard format were sent after 3 and 6 weeks. Respondents had two possibilities to fill in the questionnaire. They could either fill in the paper questionnaire they received with the first post mail, or they could complete an online questionnaire. Both versions included the same questions. In total, 983 respondents participated in the survey. The raw response rate (12.3\%) is as expected lower than in individual surveys. Our response rate is comparable with other corporate studies in Europe and the USA, where it is mostly ranging between 5\% and $10 \%$ and is at most $20-30 \%$ (Henkens et al., 2008; Kalleberg et al., 1996; Van Dalen et al., 2006).

\section{Participants}

The questionnaires were addressed to the 'Human Resource Department' of the organization. Each organization received one questionnaire with a distinct identification number (printed on the paper questionnaire and necessary to login for the online questionnaire) in order to avoid multiple answers from the same organization. Within the HR department, generally any person might have completed the questionnaire. Information on the respondents' position show that more than one-third (37\%) of the respondents are 'Chief executive officer of the HR department', about every fifth respondent was the owner of the company (18\%) or a staff member of the HR department (around 17\%). Furthermore, about $10 \%$ of the respondents were Member of the Board or of the Directors. The remaining questionnaires were completed by managers or staff members. In the following, we will refer to respondents as 'employers', even though, strictly speaking, this might not be the case. By doing so, we clearly follow other researchers who call their respondents in corporate surveys 'employers' or 'managers' (De Vries et al., 2001; Henkens, 2005; Henkens et al., 2008; Karpinska et al., 2011; Remery et al., 2003; Van Dalen et al., 2006, 2010). 


\section{Representativeness}

To make our sample as representative as possible for the Dutch organizations, we implement sampling weights and post-stratification weights. First, we use sampling weights to correct for the oversampling of large organizations. Sampling weights are defined as the inverse of the probability of selecting a unit (Kalton, 1983; Wooldridge, 2008). As the mean of the weights should be one (Kalton, 1983), we correct for this by applying weights of about 0.5 (instead of one) for those organizations that had a chance equal to one to be in our sample. All organizations that had a reduced chance to be in the sample, get sampling weights of above 1. Second, we implement post-stratification weights. These weights are calculated based on the size and the sector of the organizations in order to correct for the fact that organizations with a specific size-sector combination were more or less likely to respond than others. This way, we make our random sample of organizations more comparable with the complete population of Dutch organizations. We differentiate nine organizational size bands (10-19 employees, 20-49, 50-99, 100149, 150-199, 200-249, 250-499, 500-999, $1000+$ employees) and seven sectors according to the Dutch standard organizational classification (SBI08 - Standaard Bedrijfsindeling). For each of the resulting 36 categories, we calculate a post-stratification weight indicating how likely an organization of that size-sector combination was to be in the sample. The product of the sampling weight and the post-stratification weight provide the individual weight for each organization.

\section{Operationalization}

\section{Employability-enhancing practices}

Similarly to prior research on employability-enhancing practices directed towards older workers (Remery et al., 2003; Schaeps \& Klaassen, 1999), we identify 15 employability practices that might be used in order to retain older employees' employability and work capacity. The items comprise practices such as 'continue working in combination with part-time retirement', 'exempt older workers from working overtime' or 'take ergonomic measures'. For each of the 15 items, there are three answer categories. We ask employers (1) whether this employability-enhancing practice 'is already implemented', (2) whether it 'is/will be considered' (3) or whether it 'will not be considered' (see Table A1). The three answer categories are recoded to a binary variable in such a way that value 1 refers to the organizations that either 'already implemented' or 'consider/will consider' the measure; value 0 refers to the organizations that 'will not consider' the measure.

Before summarizing these 15 items in one scale, we assess whether these 15 employability-enhancing practices measure the same concept by applying factor analysis. Some Dutch authors and policy actors differentiate between practices that relieve older workers and those where investment takes place (Ybema, Geuskens, \& Oude Hengel, 2009). We use factor analysis with polychoric correlations because the recoded items are binary. With polychoric correlations, we take into account that variables might group together just due to their coding. The results of the factor analysis indicate that there is one primary factor with an eigenvalue of 5.80; the eigenvalue of the second is just above one (1.07). All items have factor loadings above 0.43 .

As the factor analysis revealed one concept, we summarize the 15 binary items in a sum scale. This means that one point is added to the scale for each employability practice that an organization implements or considers. No points are added to the scale if an organization does not consider implementing the practice. This results in a scale ranging 
from 0 to 15 , with higher values indicating that more employability-enhancing practices are implemented/considered by the organization. The descriptive results are provided in Table 1.

\section{Independent variables}

The age of employees in the organization is operationalized by having the respondents indicate how many per cent of the organization's workforce is older than 50 years. The size of organization is measured with the variable asking for the number of employees the organization has at the beginning of 2012. We took the natural logarithm of the organization's size in order to lessen the influence of very large organizations. ${ }^{1} \mathrm{We}$ measure existent human capital with the average educational level and the average tenure in the organization. The average educational level is operationalized by a variable asking the employers 'What is the composition of the personnel according to educational level?'. Employers could indicate the percentage of lower educated, ${ }^{2}$ medium educated ${ }^{3}$ and the percentage of higher educated workers. ${ }^{4}$ We recoded the variable in such a way that we applied weights to the three educational levels $($ low $=1$, medium $=2$, high $=3$ ) and summed the percentage of lower, medium and higher educated workers. This way, our average educational level in the organization ranges from 1 (100\% low educated) to 3 (100\% higher educated) employees. To assess the average tenure in the organization we asked 'How long on average are workers employed in your firm'. The answer categories were 1 ' $0-5$ years' (reference category), 2 ' $5-10$ years', 3 ' $10-15$ years' and 4 'more than 15 years'.

Table 1. Descriptive statistics.

\begin{tabular}{lrrrc}
\hline & Obs. $^{a}$ & Mean & SD & Range \\
\hline Employability-enhancing practices & 860 & 9.06 & 4.46 & $0-15$ \\
Percentage older workers $^{\mathrm{b}}$ & 845 & 1.15 & 15.96 & $-22.07-77.94$ \\
Size organization (log) $^{\mathrm{b}}$ & 843 & 0.13 & 1.60 & $-4.09-6.99$ \\
Average educational level & 828 & 1.84 & 0.54 & $1-3$ \\
Average tenure & & & & \\
0-5 years (ref.) & 852 & 0.13 & & $0 / 1$ \\
5-10 years & 852 & 0.34 & & $0 / 1$ \\
10-15 years & 852 & 0.33 & & $0 / 1$ \\
More than 15 years & 852 & 0.20 & & $0 / 1$ \\
Perception older workers & 799 & -0.01 & 0.49 & $-1.82-1.61$ \\
Competition through scarcity expected & & & & \\
$\quad$ No scarcity (ref.) & 835 & 0.44 & & $0 / 1$ \\
Some positions & 835 & 0.46 & & $0 / 1$ \\
$\quad$ Many positions & 835 & 0.11 & & $0 / 1$ \\
Collective labour agreement & 851 & 0.73 & & $0 / 1$ \\
Sector of organization & & & & $0 / 1$ \\
$\quad$ Agriculture and industry (ref.) & 849 & 0.35 & & $0 / 1$ \\
Trade and catering & 849 & 0.19 & & $0 / 1$ \\
$\quad$ Transport, information and communication & 849 & 0.10 & & $0 / 1$ \\
Financial and business services & 849 & 0.17 & & $0 / 1$ \\
Government and care & 849 & 0.10 & & $0 / 1$ \\
$\quad$ Culture, recreation, else & 849 & 0.10 & & \\
\hline
\end{tabular}

${ }^{a}$ For all variables with missing observations, values are imputed by ICE.

${ }^{\mathrm{b}}$ Variables are centred on their mean. 
To assess the perception of older employees within the organization, we make use of the item-battery that asked 'In your opinion, what are the consequences for your organization if the average age of the personnel increases?' Seven of these items, including statements such as 'knowledge increases', 'experience rises', 'productivity increases' or 'mobility of the personnel enhances', refer to a positive perception of older employees. Employers could evaluate these items on a scale from 1 'very unlikely' to 5 'very likely'. We conduct factor analyses (after polychoric correlations) to assess whether these items can be regarded as one scale. As the items can be summarized in one concept with an eigenvalue of 2.64 , we compute a scale based on the mean of the seven items. The resulting scale ranges from 1 to 5 , with higher values referring to more positive perceptions (Cronbach's $\alpha=0.75$ ).

Last, we asked to which extent the organization is dependent on the labour market. Employers can perceive that there is competition on the market due to scarcity in labour supply. Competition is operationalized by two dummy variables where employers could indicate whether they anticipate 'scarcity in some positions' or 'scarcity in many positions' for the future, both opposed to expecting 'no scarcity in labour supply' (reference category).

In our analyses, we control for whether the organization applies a collective labour agreement (yes $=1$ ) and six different industry sectors. The latter are included as five dummy variables in the analyses, with the reference category being agriculture and industry. The dummy variables for the sectors are: trade and catering; transport, information and communication; financial and business services; government and care; culture, recreation, else.

\section{Methods}

To which extent the employability-enhancing practices are implemented by organizations is measured with a continuous variable. We therefore employ ordinary least squares linear regressions. We include all variables in the regression analysis (Model 1) and additionally run a regression model for the interaction between the age of employees in the organization and the size of the organization (Model 2).

Total 860 respondents provided answers on the dependent variable. As about $16 \%$ of these 860 organizations would be deleted due to the list-wise deletion in the regression analyses, we imputed missing values on the independent variables by imputation using chain equation (ICE). With this iterative multivariable (imputation) regression method, all variables used in the prediction model for employability-enhancing practices are also included in the imputation model. We run 25 imputations (StataCorp LP, 2009) and report the variation between the imputed models (average relative variance increase (RVI)) below the models.

\section{Results}

\section{Descriptive picture: the implementation of employability-enhancing practices}

To assess to which extent employability-enhancing practices are used by employers to sustain their older workers' employability, we list the practices that were included in our questionnaire, together with the information in how far organizations use these as an employability investment in their older workers. Figure 1 shows that around $80 \%$ of the organizations use employability-enhancing practices such as 'taking ergonomic measures', 'employing older workers to coach younger colleagues' or 'alleviating older workers' tasks' in their agenda. In contrast, instruments such as 'developing educational 
Take ergonomic measures

Employ older workers to coach younger colleagues

Alleviate tasks of older workers

Move to less burdensome position within the organization

Continue working in combination with part-time retirement

Conduct personal interviews specifically focusing on the last career stage

Adjust working hours

Offer expanded leave/vacation opportunities for older workers

Encourage working in mixed-age teams

Exempt older workers from working overtime

Facilitate long-term care breaks

Demote position and wage (demotion)

Develop educational trajectories for older workers

Establish age limits for irregular work/ shift work

Take lengthy career breaks (e.g. sabbatical leave)
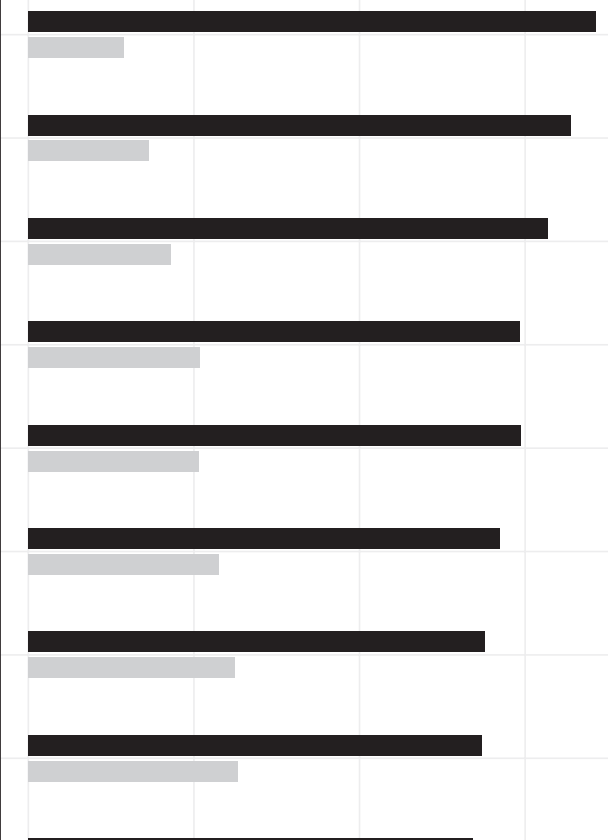

$$
-1
$$
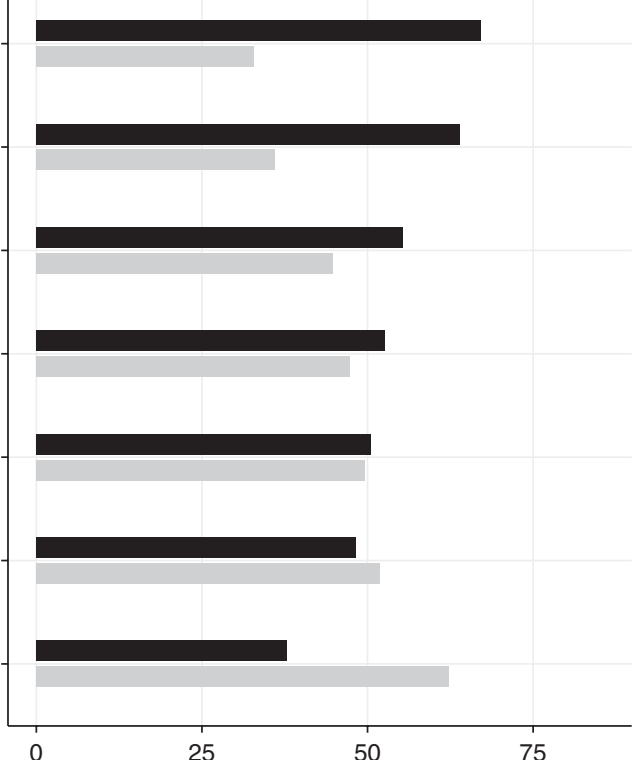

0

25 'Will not be considered'

'Already implemented'/ 'Is/will be considered'

Figure 1. Employability-enhancing practices ordered by share of organizations who implemented/ considered the practice.

trajectories for older workers', 'establishing age limits for irregular work/shift work' or 'taking lengthy career breaks' are discussed in less than $50 \%$ of the organizations.

This shows that employers especially implement, or consider implementing, practices that are not expensive (e.g. taking ergonomic measures, using older workers for coaching) 
or those that are state regulated or discussed in collective agreements (e.g. continue working in combination with part-time retirement, offering expanded leave/vacation opportunities). Those employability practices that are most expensive for the organization (e.g. taking lengthy career breaks, develop educational trajectories) are hardly ever considered to enhance the employability of older workers. This dichotomy in employability-enhancing practices resembles findings of other studies: Van Dalen et al. (2006) argue that in the Netherlands especially 'politically correct' rather than 'hard' measures are taken (p. 29). Also Remery et al. (2003) and Ybema et al. (2009) assess that mostly practices that 'spare' older workers or are part of collective agreements are implemented, whereas those that would involve actual training and investments in older workers are very infrequently considered. In the following, we assess under which conditions employers invest in employability-enhancing practices.

\section{Explanatory analyses: under which conditions do employers invest?}

In Model 1 (Table 2), we include all variables, except for the interaction between the size of the organization and the percentage of older workers. In line with the argument that investment is less likely if the costs are higher, we expected that a higher share of older workers in the organization is related to a lower investment in employability-enhancing practices. We do not find a significant association between the organization's share of older workers and the investment in employability-enhancing practices. Our age

Table 2. OLS linear regression results for implementation of employability-enhancing practices.

\begin{tabular}{|c|c|c|c|c|}
\hline & \multicolumn{2}{|c|}{ Model 1} & \multicolumn{2}{|c|}{ Model 2} \\
\hline & Coef. & $S E$ & Coef. & $S E$ \\
\hline \multicolumn{5}{|l|}{ Independent variables } \\
\hline Percentage older workers & 0.016 & 0.015 & 0.027 & 0.017 \\
\hline Size organization $(\log )$ & $0.444 * *$ & 0.154 & $0.425 * *$ & 0.153 \\
\hline Percentage older workers $\times$ size organization $(\log )$ & & & 0.013 & 0.009 \\
\hline Average educational level & 0.574 & 0.454 & 0.585 & 0.451 \\
\hline \multicolumn{5}{|l|}{ Average tenure (ref: $0-5$ years) } \\
\hline $5-10$ years & $1.829 * *$ & 0.643 & $1.807 * *$ & 0.640 \\
\hline $10-15$ years & $1.702 *$ & 0.700 & $1.652 *$ & 0.708 \\
\hline More than 15 years & 0.906 & 0.816 & 0.893 & 0.822 \\
\hline Perception older workers & $1.405^{* *}$ & 0.416 & $1.438^{* *}$ & 0.414 \\
\hline \multicolumn{5}{|l|}{ Competition through scarcity expected (ref: no) } \\
\hline Some positions & $2.274 * * *$ & 0.484 & $2.246^{* * *}$ & 0.481 \\
\hline Many positions & $2.524 * * *$ & 0.670 & $2.474 * * *$ & 0.669 \\
\hline \multicolumn{5}{|l|}{ Control variables } \\
\hline Collective labour agreement & 0.317 & 0.483 & 0.318 & 0.475 \\
\hline \multicolumn{5}{|c|}{ Sector of organization (ref: agriculture and industry) } \\
\hline Trade and catering & -0.489 & 0.515 & -0.432 & 0.520 \\
\hline Transport, information and communication & $-1.489^{*}$ & 0.705 & $-1.499^{*}$ & 0.698 \\
\hline Financial and business services & -0.463 & 0.648 & -0.432 & 0.640 \\
\hline Government and care & 0.166 & 0.670 & 0.135 & 0.688 \\
\hline Culture, recreation, else & -1.079 & 0.758 & -1.026 & 0.755 \\
\hline Constant & $5.590 * * *$ & 1.190 & $5.582 * * *$ & 1.186 \\
\hline Observations & 860 & & 860 & \\
\hline Imputations & 25 & & 25 & \\
\hline Average RVI & 0.079 & & 0.086 & \\
\hline
\end{tabular}

${ }^{*} p<0.05,{ }^{* * *} p<0.01,{ }^{* * * *} p<0.001$. 
hypothesis (H1) can, therefore, not be supported. Organizational size was expected to be positively related to the provision of employability-enhancing practices $(\mathrm{H} 2)$. We find support for our rationale: the larger the organizations are, the more employability practices are on employers' agenda. In Model 2, we included the interaction effect between the percentage of older workers and the size of the organization (H3). We do not find support for our expectation that investment is taking especially place in organizations where a high number of older workers are combined with larger organizations.

We test the existent human capital hypothesis (H4) by considering the average educational level in the organization and the average tenure. If more capital is available in an organization, we assumed to find more investment in employability-enhancing measures. A higher educational level is not significantly related to the provision of employability-enhancing practices. However, the analyses reveal that the average tenure in the organization is positively related to employability. This means, especially in organizations where the mean tenure of workers is between 5 and 15 years, employers provide more employability practices compared with the organizations where the tenure is below 5 years. This effect of tenure comes on top of the effect of the share of older workers (age). Regarding the existing human capital hypothesis (H4), we conclude that if an organization has a higher level of existent human capital, then employers also implement more employability practices.

Regarding the perception hypothesis (H5), we test whether a more positive perception of older workers is related to the provision of more employability practices. Our results show that employers invest more in the employability of their older workers the better they perceive older workers. These results support our hypothesis (H5).

Last, we investigate whether the organization's dependency on the labour market, in terms of competition through scarcity in labour supply (H6), relates to their investment in employability practices. Organizations' investments appear to be dependent on the labour market in terms of competition for scarce workers. Our results show that employers implement more employability-enhancing practices if they expect that the organization has to deal with a scarcity to fill some or many positions. This finding supports our theoretical expectations.

Regarding the control variables, we assess the following: whether organizations apply a collective labour agreement does not seem to matter for the implementation of employabilityenhancing practices. Also the sector of the organization does hardly seem to play a role. Only organizations operating in 'Transport, Information and Communication' seem to implement fewer employability practices compared with those in 'Agriculture or Industry'.

\section{Conclusion and discussion}

This article set out to investigate the extent and conditions under which employers provide employability-enhancing practices specifically focusing on older workers. Studying employability practices directed towards older workers rather than assessing the role of 'general' employability practices is relevant in the context of an ageing population and workforce. We embedded our expectations in a context where the costs of investing in employability-enhancing practices played a role but employers made decisions dependent on organizational and labour market characteristics and formulated hypotheses both for underinvestment and investment in employability practices. Empirically, we made use of a large company data set with information on 860 Dutch organizations to test our expectations. These encompassing data allow drawing general conclusions about Dutch organizations and are comparable with other Dutch data sets (Henkens, 2005; Henkens et al., 2008). 
Our findings can be summarized as follows. First, regarding the implementation of employability-enhancing practices, we find that especially those practices that are most feasible, very easy to implement and least expensive are on organizations' employability agenda. Such measures include alleviating older workers' tasks, taking ergonomic measures or using older workers for coaching. Measures that are supported through occupational pension schemes or formulated in collective labour agreements, such as parttime retirement, additional leave days for older workers or adjusting their working hours, are also considered by employers. This clearly shows that employers are generally not averse to implement practices that help older workers sustain their employability. However, exactly those employability practices that are increasingly important in the changing economy, where older workers will need to participate longer, are rarely implemented or considered. Expensive measures, those that allow workers to detach from the organization for a longer period, or involve organizational restructuring are not even considered by employers. Examples for these practices are: developing educational trajectories for older workers, facilitating long-term care breaks and career breaks (sabbatical leave). These descriptive results are in line with prior research assessing that rather 'politically correct' or collectively agreed upon than 'hard' measures are used in organizations (Remery et al., 2003; Van Dalen et al., 2006). Furthermore, we replicate research noting that employability practices can be subdivided into practices that relieve older workers' tasks or 'spare' them, and those where investment in workers' employability takes place (Van Dalen et al., 2006; Ybema et al., 2009). In an ageing population, it will become important for both public and organizational policy to increase the attention on practices that allow older workers to make considerable changes in their career paths. Even though this might involve that jobs are re-designed (Conen et al., 2011; Hedge et al., 2006; Taylor \& Walker, 1998), older workers' participation on the labour market might be prolonged as a result.

In the second part, we investigated under which conditions employers implement employability-enhancing practices directed towards older workers. We find that employers in larger organizations invest more in employability practices. This is in line with our theoretical explanation that the marginal costs of an investment, such as the provision of employability practices, decreases if it is made for a larger number of workers. This finding might also be explained by the internal labour markets larger organizations have. If employers intend to recruit their own workers, the incentive to invest in workers is higher.

The hypothesis that more employability-enhancing practices are provided in organizations with a higher share of older workers is not supported (H1). This is surprising because the practices we studied are explicitly directed towards older workers. Further research is advised to study whether the number of older workers increases the provision of employability practices. We also investigate employers' perceptions towards older workers. In organizations where older workers are perceived more positively, the provision of employability-enhancing practices is higher. Theoretically, this finding can be explained by organizational culture theory that supposes that specific perceptions are shared among the members of an organization (Schein, 1985; Zacher \& Gielnik, 2014). This means that even employers that might not have daily contact with older workers share the positive perception of these. The established organizational culture might thus increase investments in older workers' employability. We also included an interaction between the perceptions towards older workers and the percentage of older workers in the organization (results not reported). A higher fraction of older workers in an organization combined with positive perceptions does, however, not appear to play a significant role for the implementation of employability practices. 
Finally, our analyses reveal that the labour market dependency of the organization plays a role. Especially in organizations where employers expect a scarcity in labour supply for the future, more investment in employability practices takes place. This can be interpreted in several ways. Either, employers invest in their older workers to keep them capable and employable for a longer time, or employers invest in them in order to increase the attractiveness of the organization. This might pay off in two ways; it might detain workers from leaving for a different organization (De Grip et al., 2004; De Vries et al., 2001) and, in general, attract new employees (De Vries et al., 2001; Knoke \& Kalleberg, 1994; Lado \& Wilson, 1994). Employers might thus use employability-enhancing practices as a tool for competitive advantage.

There are several limitations of our article of which we address the most important in the following. First, as it is common with company surveys, the response rate of our study is low. Studies investigating organizations usually have to deal with high nonresponse (Henkens et al., 2008; Kalleberg et al., 1996; Van Dalen et al., 2006); one reason is that respondents can often not be personally addressed because it is not exactly known who fulfils which position in the organization. Furthermore, and relevant in our case, we did not have telephone numbers or email addresses of the organizations, which made it impossible to approach respondents that way. Anticipating a predictably low response rate and in order to guarantee a large enough sample of Dutch organizations, we sampled 8000 organizations. Even though the non-response is high, we are confident that our analyses relying on 860 organizations reflect the Dutch organizational landscape. This is even more the case because we applied sampling and stratification weights.

Second, the employers participating in our survey are a rather heterogeneous group. As discussed in the description of our respondents, more than one-third of the respondents fulfilled the position of 'Chief executive officer of the HR department', about one-fifth of the respondents were the owner of the company and another fifth were the staff member of the HR department. This exemplifies that whom we call 'employer' in this study is not exclusively 'employer' in the strict sense. However, by making this decision in wording, we follow the example of many prior studies (De Vries et al., 2001; Henkens, 2005; Henkens et al., 2008; Karpinska et al., 2011; Remery et al., 2003; Van Dalen et al., 2006, 2010). Therefore, we are confident that our respondents are taking HR decisions or are involved in these.

Third, our study has a cross-sectional design; thus, we only know which employability practices employers considered to implement in the period the data were collected. These considerations (intentions) do not necessarily reflect their actual behaviour. In this light, organizations might easily indicate to consider specific employability practices as a way of providing a 'socially desirable' answer. However, it becomes clear that social desirability bias is probably limited because a substantive fraction of employability-enhancing practices are not even considered by organizations (cf. Figure 1). For further research, it would be interesting to repeat the data collection to assess which of the practices, that were initially considered, are implemented in the following.

To conclude, our study shows that both organizational and labour market characteristics affect employers' decisions whether to provide employability-enhancing practices for their older workers. It appears that for example especially larger organizations invest in their older workers' employability. Policy measures might be discussed as a possible means to increase the incentives for smaller firms to invest in their workers. Financial subsidies might trigger smaller organizations to provide employabilityenhancing practices. The expansion of employability practices is especially relevant in the context of an ageing population and ageing workforce. Under these circumstances, a 
higher labour market participation of older workers and a delayed retirement is becoming ever more important. In addition, the type of employability-enhancing practices should be addressed more frequently in policy debates. As there is no 'one size fits all' employability practice, employer-provided practices that increase older workers' employability should consider the requirements of older workers as compared with their younger colleagues, but leave room for individual wishes.

\section{Disclosure statement}

No potential conflict of interest was reported by the authors.

\section{Funding}

This research is funded by the project 'Productive in multiple ways: In search for activating institutions', Stichting Instituut Gak [SZ2025].

\section{Notes}

1. Even though we sampled organizations with more than ten employees, there might be organizations that recently laid-off workers; therefore, the organizational size might be below 10.

2. Dutch correspondent degrees: MAVO [Middelbaar Algemeen Voortgezet Onderwijs], VMBO [Voorbereidend Middelbaar Beroepsonderwijs], LBO [Lager Beroepsonderwijs], LO [Lager Onderwijs].

3. Dutch correspondent degrees: HAVO [Hoger Algemeen Voortgezet Onderwijs], VWO [Voorbereidend Wetenschappelijk Onderwijs], MBO [Middelbaar Beroepsonderwijs].

4. Dutch correspondent degrees: HBO [Hoger Beroepsonderwijs], WO [Wetenschappelijk Onderwijs].

\section{References}

Antikainen, A. (2001). Is lifelong learning becoming a reality? The case of Finland from a comparative perspective. European Journal of Education, 36, 379-394.

Arrow, K. J. (1973). The theory of discrimination. In O. Ashenfelter \& A. Rees (Eds.), Discrimination in labor markets (pp. 3-33). Princeton, NJ: Princeton University Press.

Becker, G. S. (1964). Human capital. New York, NY: National Bureau of Economic Research.

Bishop, J. H. (1996). What we know about employer-provided training: A review of literature (CAHRS Working Paper \#96-09). Ithaca, NY: Cornell University, School of Industrial and Labor Relations, Center for Advanced Human Resource Studies.

Brown, C., Hamilton, J., \& Medoff, J. (1990). Employers large and small. Cambridge, MA: Harvard University.

Canduela, J., Dutton, M., Johnson, S., Lindsay, C., McQuaid, R. W., \& Reaside, R. (2012). Ageing, skills and participation in work-related training in Britain: Assessing the position of older workers. Work, Employment and Society, 26, 42-60.

Chui, W. C. K., Chan, A. W., Snape, E., \& Redman, T. (2001). Age stereotypes and discriminatory attitudes towards older workers: An east-west comparison. Human Relations, 54, 629-661.

Conen, W., Henkens, K., \& Schippers, J. (2011). Are employers changing their behavior toward older workers? An analysis of employers' survey 2000-2009. Journal of Aging \& Social Policy, $23,141-158$.

Cuddy, A. J., \& Fiske, S. T. (2002). Doddering but dear: Process, content and function in stereotyping older persons. In T. Nelson (Ed.), Ageism: Stereotyping and prejudice against older persons (pp. 3-26). Cambridge, MA: MIT Press.

De Grip, A., Van Loo, J., \& Sanders, J. (1999). Employability in bedrijf. Naar een employabilityindex voor bedrijfssectoren [Employability in action. Towards an employability index for industry sectors]. Tijdschrift voor arbeidsvraagstukken, 15, 293-312. 
De Grip, A., Van Loo, J., \& Sanders, J. (2004). The industry employability index: Taking account of supply and demand characteristics. International Labour Review, 143, 211-233.

De Vries, S., Gründemann, R., \& Van Vuuren, T. (2001). Employability policy in Dutch organizations. International Journal of Human Resource Management, 12, 1193-1202.

Finkelstein, L. M., \& Burke, M. J. (1998). Age stereotyping at work: The role of rater and contextual factors on evaluations of job applicants. The Journal of General Psychology, 125, 317-345.

Forrier, A., \& Sels, L. (2003). Temporary employment and employability. Training opportunities and efforts of temporary and permanent employees in Belgium. Work, Employment and Society, $17,641-666$.

Fugate, M., Kinicki, A. J., \& Ashforth, B. E. (2004). Employability: A psycho-social construct, its dimensions, and applications. Journal of Vocational Behavior, 65, 14-38.

Gazier, B. (1999). Employability: Concepts and policies. Berlin: Institute for Applied SocioEconomics.

Gazier, B. (2001). Employability - The complexity of a policy notion. In P. Weinert, M. Baukens, P. Bollérot, M. Pineschi-Gapènne, \& U. Walwei (Eds.), Employability: From theory to practice (pp. 3-23). New Brunswick, NJ: Transaction Publishers.

Groot, W., \& Maassen van den Brink, H. (2000). Education, training and employability. Applied Economics, 32, 573-581.

Hall, D. T. (2002). Careers in and out of organizations. Thousand Oaks, CA: Sage.

Heckman, J. (2000). Policies to foster human capital. Cambridge, MA: National Bureau of Economic Research.

Hedge, J. W., Borman, W. C., \& Lammlein, S. E. (2006). The aging workforce: Realities, myths, and implications for organizations. Washington, DC: American Psychological Association.

Henkens, C. J. I. M. (2005). Stereotyping older workers and retirement: The managers' point of view. Canadian Journal of Aging, 24, 353-366.

Henkens, K., Remery, C., \& Schippers, J. (2008). Shortages in an ageing labour market: An analysis of employers' behavior. The International Journal of Human Resource Management, 19, $1314-1329$.

Hurd, M., \& McGarry, K. (1993). The relationship between job characteristics and retirement (Working Paper No. 4558). Cambridge, MA: National Bureau of Economic Research.

Kalleberg, A. L., Knoke, D., Marsden, P. V., \& Spaeth, J. L. (1996). Organizations in America: Analyzing their structures and human resource practices. Thousand Oaks, CA: Sage.

Kalton, G. (1983). Introduction to survey sampling. Beverly Hills, CA: Sage.

Karpinska, K., Henkens, K., \& Schippers, J. (2011). The recruitment of early retirees: A vignette study of the factors that affect managers' decisions. Ageing and Society, 31, 570-589.

Knoke, D., \& Ishio, Y. (1994). Occupational training, unions, and internal labor markets. American Behavioral Scientist, 37, 992-1016.

Knoke, D., \& Kalleberg, A. L. (1994). Job training in U.S. organizations. American Sociological Review, 59, 537-546.

Lado, A. A., \& Wilson, M. C. (1994). Human resource systems and sustained competitive advantage: A competency-based perspective. Academy of Management Review, 19, 699-727.

Lazear, E. P. (1979). Why is there mandatory retirement? Journal of Political Economy, 87, $1261-1274$.

Loretto, W., Duncan, C., \& White, P. J. (2000). Ageism and employment: Controversies, ambiguities and younger people's perceptions. Ageing and Society, 20, 279-302.

McCann, R., \& Giles, H. (2002). Ageism in the workplace: A communication perspective. In T. Nelson (Ed.), Ageism: Stereotyping and prejudice against older persons (pp. 163-199). Cambridge, MA: MIT Press.

Mincer, J. (1962). On-the-job training: Costs, returns and some implications. Journal of Political Economy, 70, 50-79.

Phelps, E. (1972). The statistical theory of racism and sexism. American Economic Review, 62, $659-661$.

Picchio, M., \& van Ours, J. C. (2011). Retaining through training; even for older workers (Discussion Paper No. 2011-040). Tilburg: CentER, Tilburg University.

Posthuma, R. A., \& Campion, M. A. (2009). Age stereotypes in the workplace: Common stereotypes, moderators, and future research directions. Journal of Management, 35, 158-188. 
Remery, C., Henkens, K., Schippers, J., \& Ekamper, P. (2003). Managing an aging workforce and a tight labor market: Views held by Dutch employers. Population Research and Policy Review, $22,21-40$.

Sanders, J., \& De Grip, A. (2004). Training, task flexibility and the employability of low-skilled workers. International Journal of Manpower, 25, 73-89.

Schaeps, M. J. M., \& Klaassen, C. (1999). Ouderenbeleid. Een onderzoek naar maatregelen in ondernemingen en afspraken tussen sociale partners met betrekking tot de arbeidsparticipatie van oudere werknemers [Policies for the elderly. A study about company measures and agreements between social partners regarding labor force participation of older workers]. The Hague, SZW/Arbeidsinspectie.

Schein, E. H. (1985). Organizational culture and leadership. San Francisco, CA: Jossey-Bass.

Schein, E. H. (1990). Organizational culture. American Psychologist, 45, 109-119.

Siegrist, J., \& Wahrendorf, M. (2010). Quality of work, health and early retirement: European comparisons (Working Paper No. 224-2010). Mannheim: Mannheim Research Institute for the Economics of Aging.

Siegrist, J., Wahrendorf, M., Von dem Knesebeck, O., Jürges, H., \& Börsch-Supan, A. (2007). Quality of work, well-being, and intended early retirement of older employees - Baseline results from the SHARE study. European Journal of Public Health, 17, 62-68.

StataCorp LP. (2009). Stata multiple-imputation reference manual. Release 11. College Station, TX: Stata Press.

Tamkin, P., \& Hillage, J. (1999). Employability and employers: The missing piece of the jigsaw (Report No. 361). Brighton: Institute for Employment Studies.

Taylor, P., \& Walker, A. (1998). Employers and older workers: Attitudes and employment practices. Ageing and Society, 18, 641-658.

Thurow, L. C. (1975). Generating inequality: Mechanisms of distribution in the U.S. New York, NY: Basic Books.

Van Dalen, H., Henkens, K., Henderikse, W., \& Schippers, J. (2006). Dealing with an ageing labour force: What do European employers expect and do? (Report No. 73). den Haag: NIDI.

Van Dalen, H., Henkens, K., \& Schippers, J. (2010). Productivity of older workers: Perceptions from employers and employees. Population and Development Review, 36, 309-330.

Waldman, D. A., \& Avolio, B. J. (1986). A meta-analysis of age differences in job performance. Journal of Applied Psychology, 71, 33-38.

Warwick Report. (2006). Ageing and employment: Identification of good practice to increase job opportunities and maintain older workers in employment. Final report. Munich: Warwick Institute for Employment Research, University of Warwick and Economix Research \& Consulting.

Wooldridge, J. M. (2008). Probabilistic sampling. In T. Rudas (Ed.), Handbook of probability. Theory and applications (pp. 187-203). Thousand Oaks, CA: Sage.

Ybema, J. F., Geuskens, G., \& Oude Hengel, K. (2009). Oudere werknemers en langer doorwerken: Secundaire analyses op de NEA, het NEA-cohortonderzoek en de WEA [Older workers and working longer: Secondary analyses based on the Netherlands Working Conditions Survey (NEA), NEA cohort research and the WEA]. Hoofddorp: TNO.

Zacher, H., \& Gielnik, M. M. (2014). Organizational age cultures: The interplay of chief executive officers' age and attitudes toward younger and older employees. International Small Business Journal, 32, 327-349. 


\section{Appendix}

Table A1. Percentages of organizations implementing or considering the 15 organizational measures for age-conscious personnel policy.

\begin{tabular}{|c|c|c|c|}
\hline & $\begin{array}{c}\text { Already } \\
\text { implemented }\end{array}$ & $\begin{array}{l}\text { Is/will be } \\
\text { considered }\end{array}$ & $\begin{array}{l}\text { Will not be } \\
\text { considered }\end{array}$ \\
\hline $\begin{array}{l}\text { Continue working in combination with part-time } \\
\text { retirement }\end{array}$ & 27.9 & 45.9 & 26.2 \\
\hline Exempt older workers from working overtime & 27.7 & 36.2 & 36.1 \\
\hline Develop educational trajectories for older workers & 12.8 & 36.9 & 50.3 \\
\hline $\begin{array}{l}\text { Offer expanded leave/vacation opportunities for } \\
\text { older workers }\end{array}$ & 42.9 & 25.3 & 31.8 \\
\hline Alleviate older workers' tasks & 32.8 & 45.4 & 21.8 \\
\hline $\begin{array}{l}\text { Conduct personal interviews specifically focusing } \\
\text { on the last career stage }\end{array}$ & 18.4 & 52.6 & 29.0 \\
\hline Adjust working hours & 26.6 & 42.7 & 30.6 \\
\hline Facilitate long-term care breaks & 17.7 & 38.1 & 44.2 \\
\hline Demote position and wage (demotion) & 7.7 & 44.8 & 47.6 \\
\hline Take lengthy career breaks (e.g. sabbatical leave) & 8.8 & 29.1 & 62.1 \\
\hline Take ergonomic measures & 44.7 & 40.3 & 15.0 \\
\hline Establish age limits for irregular work/shift work & 20.0 & 27.5 & 52.5 \\
\hline $\begin{array}{l}\text { Employ older workers to coach younger } \\
\text { colleagues }\end{array}$ & 31.5 & 49.7 & 18.8 \\
\hline Encourage working in mixed-age teams & 27.5 & 39.1 & 33.3 \\
\hline $\begin{array}{l}\text { Move to less burdensome position within the } \\
\text { organization }\end{array}$ & 24.2 & 50.4 & 25.4 \\
\hline
\end{tabular}

